\title{
The influence of glucose and peat extract additions on the spring recruitment of Gonyostomum semen from the sediments
}

\author{
Wojciech Pęczuła • Magdalena Suchora • \\ Grażyna Żukowska
}

Received: 30 May 2014/Revised: 2 September 2014/ Accepted: 6 October 2014/Published online: 12 October 2014

(C) The Author(s) 2014. This article is published with open access at Springerlink.com

\begin{abstract}
The effect of two various forms of DOC on the Gonyostomum semen recruitment from sediments was conducted under experimental laboratory conditions. We tested the hypothesis that DOC is a factor enhancing spring recruitment of the species by exposing sediments from a humic lake with a 17-year bloom history, to three various DOC additions (two solutions of glucose and one solution of a peat extract). Sediments and lake water were incubated for 14 days at $16^{\circ} \mathrm{C}$, in $14: 10 \mathrm{~h}$ light:dark cycle, with germling and adult cell abundance ascertained in the water every third day, and water parameters every seventh day. Our important findings were that (1) Gonyostomum recruitment was uneven and the period of germination was relatively short; (2) all treatments significantly affected germling occurrence; however, sugar-derived DOC seemed to suppress the recruitment, whereas peat extract improved it. Due to the additional phosphorus load in peat treatment (against phosphorus-free sugar treatments), it is likely that it played a
\end{abstract}

Handling editor: Judit Padisak

W. Pęczuła $(\square) \cdot$ M. Suchora

Department of Hydrobiology, University of Life Sciences in Lublin, Lublin, Poland

e-mail: wojciech.peczula@up.lublin.pl

G. Żukowska

Institute of Soil Sciences, Environment Engineering and Management, University of Life Sciences in Lublin,

Lublin, Poland major role in the observed differences, however, our results did not exclude the potential role of peatderived DOC forms. In conclusion, we proposed that Gonyostomum expansion is supported by enhanced recruitment from sediment seed banks related to water chemistry alterations, driven by the climate change.

Keywords Gonyostomum semen · Dissolved organic carbon · Recruitment - Cyst germination . Lake sediments

\section{Introduction}

Gonyostomum semen (Ehr.) Diesing is a bloomforming flagellate species that often occurs in humic lakes across Europe. During the last three decades, the number of reports on blooms of this alga in European freshwaters has increased (Cronberg et al., 1988; Lepistö et al., 1994; Noges \& Laugaste, 2002; Willen, 2003; Rengefors et al., 2012; Pęczuła, 2013; Karosiene et al., 2014). The factors enabling the expansion and blooming of Gonyostomum semen are still under discussion. Among the hypothesized drivers for the observed increased distribution and abundance are eutrophication (Eloranta \& Palomäki, 1986; Hongve et al., 1988; Laugaste, 1992; Lepistö \& Saura, 1998), acidification (Cronberg et al., 1988; Korneva, 2000; Hansson, 2000), calcification of acid lakes (Hutorowicz, 1993), increased dissolved organic carbon (DOC), and fulvic acid concentrations (Findlay et al., 
2005; Rengefors et al., 2008), as well as the extension of the growing season related to the climate change (Rengefors et al., 2012), and the alternations in planktonic food webs (consisting of a fall in the abundance of filter-feeding Cladocera) (Hansson, 2000; Hehmann et al., 2001).

Like some other flagellate algae, Gonyostomum semen forms the resting cysts during autumn. These overwinter in sediments in seed banks, and after a dormancy period lasting at least 11 weeks, germinate and form a new generation in the water column (Figueroa \& Rengefors, 2006; Rengefors et al., 2012). It is supposed that the benthic cyst formation in planktonic algae is an adaptation strategy enabling survival during unfavorable periods (Fryxell, 1983; Hansson, 2000), and the spring or summer encystment plays a crucial role in the bloom initiation or the seasonal succession (Anderson \& Wall, 1978; Anderson \& Rengefors, 2006). Although there are many studies about the factors which regulate algal cyst germination (Agrawal, 2009), the knowledge about Gonyostomum semen recruitment from sediments is poor. Yet, there is evidence that the cyst germination of this species is affected by temperature (Figueroa \& Rengefors, 2006; Rengefors et al., 2012), phosphorus addition (Findlay et al., 2005), and the presence of Cladocera in the water column (Hansson, 1996).

An increased DOC concentration is supposed to promote Gonyostomum semen development in lakes, as the species probably uptakes organic compounds by osmotrophy - directly as fulvic acids or by cell lysis of other microorganisms (Rengefors et al., 2008). A large fraction of DOC in lakes is colored and composed of fulvic and humic acids of allochthonous origin (Schindler et al., 1992; Wetzel, 1992). The load of this matter results in worsened light climate in lakes (Nürnberg \& Shaw, 1998; Pace \& Cole, 2002), which is also proposed as a factor favoring Gonyostomum semen domination, due to the species sensitivity to excessive insolation (Findlay et al., 2005). The DOC concentration and its structure in humic lakes are related to various factors. Among these are: the area of lake catchment, the land cover in the catchment, the area of the lake, winter and summer precipitation, the time of snowmelt, and other climatic factors. Hence, there is no common pattern in seasonal changes in DOC concentration in humic lakes (Pace \& Cole, 2002; Vuorenmaa et al., 2006). Nevertheless, some evidence from central Europe showed that the maximal DOC concentration in any lake may be reached in May or June (Górniak et al., 2002). In small humic lakes in central-eastern Poland, the water color values in May are often higher than in July or September, indicating a high load of colored allochthonous DOC derived from snowmelt and spring rainfall (Pęczuła, unpublished). Spring Gonyostomum recruitment may be, therefore, affected by a DOC pulse from the catchment, particularly because the month of May is supposed as the period in which the species cysts have the best encystment ability after 6-7 months of dormancy (Rengefors et al., 2012).

We have put forward the hypothesis that the dissolved organic carbon can be one of the factors enhancing Gonyostomum semen spring recruitment from the sediments. We aimed to test it in laboratory conditions by exposing sediments from a humic lake in which Gonyostomum blooms are observed, to various glucose and peat extract additions.

\section{Methods}

In April 2013, a laboratory experiment was conducted to stimulate the appearance of Gonyostomum from lake sediments, by adding various organic carbon additions: glucose and peat extract. We had decided to use the carbohydrate as it is a colorless, nitrogen- and phosphorus-free form of DOC, and it was previously applied in other experimental studies concerning DOC addition to lake ecosystem (Blomqvist et al., 2001).

Sediment samples were collected in late April, from Lake Płotycze (eastern Poland, N51 ${ }^{\circ} 23^{\prime} 34.9^{\prime \prime}$, E23 $\left.37^{\prime} 03.8^{\prime \prime}\right)$. This lake is significant in that the algae form a high biomass and dominate the phytoplankton structure since the end of the last century (Pęczuła, 2007, 2013). Detailed limnological characteristics of the lake can be found in Pęczuła \& Szczurowska (2013). The sampling was conducted during the ice-melting period, in the ice-free littoral area ( $2 \mathrm{~m}$ of depth), when the central part of the lake was still covered with a thin $(\sim 1 \mathrm{~cm})$ layer of ice. A total of 12 sediment cores with above-sediment water were taken using a Uwitec gravity core sampler (diameter $6 \mathrm{~cm}$ ). Additionally, $20 \mathrm{dm}^{3}$ of lake water was sampled by way of a Ruttner sampler, from the depth $0.5 \mathrm{~m}$ above the sediments. All samples were kept in the dark and protected against heating (by 
covering with foamed polystyrene insulation) during the $2 \mathrm{~h}$ transportation to the laboratory.

In the laboratory, $20 \mathrm{dm}^{3}$ of sampled lake water was filtered through a GF/C fiber-glass filter. The initial DOC concentration in this water was $23.0 \pm 0.2 \mathrm{mg} \mathrm{dm}^{-3}, \mathrm{pH} 6.4$, electrolytic conductivity $30 \mu \mathrm{S} \mathrm{cm}^{-1}$, and phosphate concentration $0.014 \pm 0.005 \mathrm{mg} \mathrm{dm}^{-3}$. The water above the sediments from the core tubes was carefully removed by way of a thin pipe, and replaced by $1.2 \mathrm{dm}^{3}$ of the filtered lake water that had incorporated the various treatment additions. The experimental design consisted of three replicated controls (marked as $\mathrm{C}$ ) and three types of treatments (in three replications each). The first two treatments included two various solutions of glucose: $15 \mathrm{mg}$ (marked as G5) and $30 \mathrm{mg}$ (marked as G10) dissolved in $1.2 \mathrm{dm}^{3}$ of filtered lake water, giving an assumed addition of 5 and $10 \mathrm{mg} \mathrm{C} \mathrm{dm}^{-3}$. The actual addition of glucose-derived DOC to the lake water was then analytically verified at $4.6 \pm 0.8$ and $7.5 \pm 0.7 \mathrm{mg} \mathrm{dm}^{-3}$, respectively. The third treatment consisted of one solution of a peat extract $(84 \mathrm{mg}$ DOC $\mathrm{dm}^{-3}$ ), marked as P. The extract was obtained by boiling $0.3 \mathrm{dm}^{3}$ of filtered lake water with $3 \mathrm{~g}$ of fresh peat, sampled from the transitional fen surrounding the lake, and filtering this through a GF/C fiber-glass filter. Mixing $300 \mathrm{ml}$ of this extract with $0.9 \mathrm{dm}^{3}$ of lake water gave an addition of $4.0 \pm 0.7$ DOC $\mathrm{dm}^{-3}$ to the lake water.

The tubes were then put in a growth cabinet at $16^{\circ} \mathrm{C}$ (which is regarded as the best for germling viability, Figueroa \& Rengefors, 2006), with a light: dark cycle of $14: 10 \mathrm{~h}$, at a light intensity of $1.0 \mu \mathrm{mol} \mathrm{m}^{-2} \mathrm{~s}^{-1}$ at the surface of the sediments. The experiment lasted for 14 days. At day 1, 7, and 14, samples of $0.13 \mathrm{dm}^{3}$ were taken from the middle depth of the water column in each tube and the loss of water was replaced by the same amount of filtered lake water stored in darkness at $4{ }^{\circ} \mathrm{C}$. Due to the low oxygen conditions observed at the seventh day sampling, the above-sediment water in all experimental tubes was aerated using a standard aquarium pump for $5 \mathrm{~min}$. This was done to improve oxygen content, as anoxic or very low oxygen conditions are known to inhibit or prevent germination of algal cysts (Anderson et al., 1987; Ishikawa \& Taniguchi, 1994; Kremp \& Anderson, 2000), and these conditions would disrupt the experiment. Another rationale for this manipulation was the attempt of mimicking the mixing conditions in temperate lakes occurring in spring after ice melting. Dissolved oxygen concentration, $\mathrm{pH}$, and conductivity were measured in the samples using a YSI556 Multi Probe (MPS). In addition, phosphates concentration was measured using a molybdate method (Hermanowicz et al., 1976), while dissolved organic carbon was determined using a TOC- $\mathrm{V}_{\mathrm{CSH}}$ Schimadzu analyzer. Beyond this work, a subsample of $0.02 \mathrm{dm}^{3}$ was fixed with a Lugol solution and, subsequently, examined for Gonyostomum abundance using an inverted microscope and the Utermöhl method (Vollenweider, 1969). Two additional samples $\left(0.02 \mathrm{dm}^{3}\right)$ for Gonyostomum analyses were taken at day 4 and 11 . During microscopic examination, we have counted small cells (width: $16.2 \pm 2.1 \mu \mathrm{m}$, length: $20.2 \pm$ $3.2 \mu \mathrm{m}$ ) and large cells (width: $28.3 \pm 6.1 \mu \mathrm{m}$, length: $45.1 \pm 9.2 \mu \mathrm{m}$ ) separately. Small forms were classified as germlings (being up to $24 \mathrm{~h}$ after germination) and the others, as mature cells (Figueroa \& Rengefors, 2006).

In order to determine the significance of differences between chemical compounds in the control and experimental tubes, one-way ANOVA analysis with Tukey's test was performed. As the two factors showed significant differences (DOC and $\mathrm{P}-\mathrm{PO}_{4}$ ), the influence of these on the number of germs was verified using main effect analysis of variance (ANOVA). The test of Kołmogorow-Smirnow was used to verify the normal distribution of the collected data. Both analyses were performed in STATISTICA 7.0.

\section{Results}

The initial DOC concentration in the control tubes amounted to $22.3 \pm 0.9 \mathrm{mg} \mathrm{dm}^{-3}$. What is more, the addition of glucose in treatments resulted in significantly higher values of the parameter $(27.6 \pm$ $0.9 \mathrm{mg} \mathrm{dm}^{-3}$ in G5, $F=52.5, P<0.01$, ANOVA; $29.5 \pm 2.0 \mathrm{mg} \mathrm{dm}^{-3}$ in $\mathrm{G} 10, F=4.56, P<0.01$, ANOVA). In the P and G5 tubes comparable DOC concentrations were obtained $\left(27.1 \pm 1.1 \mathrm{mg} \mathrm{dm}^{-3}\right.$ in P tanks). During the experiment, a decrease in DOC content was observed in all treatment tubes, reaching on the last day, a level similar to that of the control tubes, which was \pm constant throughout the study (Fig. 1a). The addition of DOC in the experimental tanks was reflected in an increase of the water color only in the $\mathrm{P}$ tanks $(48.9 \pm 1.4-53.2 \pm 1.2 \mathrm{mg} \mathrm{Pt}$ 

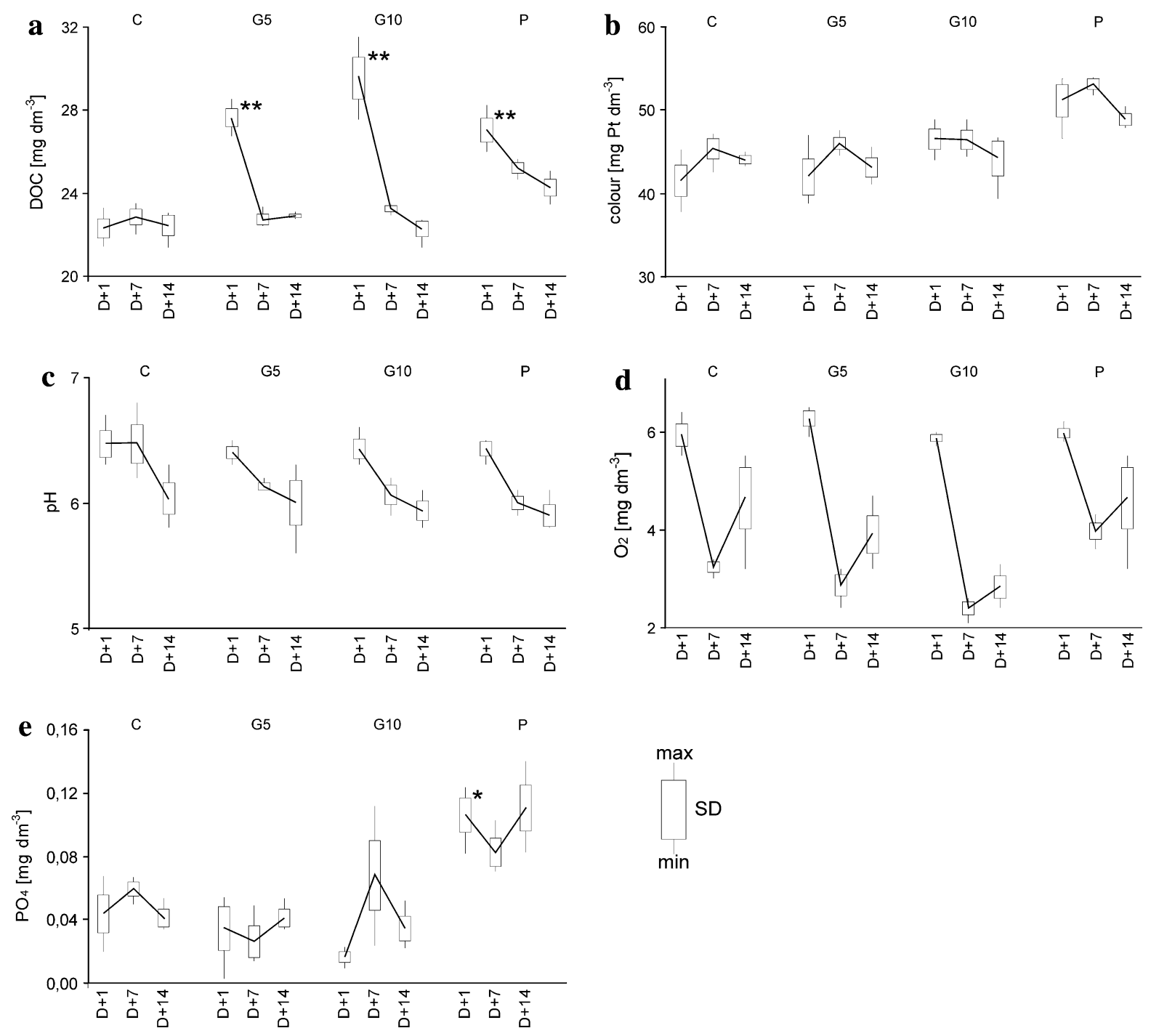

Fig. 1 Changes of a dissolved organic carbon, b water color, c $\mathrm{pH}$, d dissolved oxygen, and e phosphates in control and experimental tanks ( $C$ control, $G 55 \mathrm{mg}$ of glucose addition, $G 1010 \mathrm{mg}$ of glucose addition, $P$ peat extract addition; $D+1$,

$\mathrm{dm}^{-3}$ ). However, in all tubes, a similar pattern of changes during the experiment appeared: an initial increase followed by a decrease (Fig. 1b). Initial water $\mathrm{pH}$ in all tanks was nearly the same (ca. 6.4), and, consequently, decreased to 5.9-6.0 (Fig. 1c). Dissolved oxygen concentrations measured on the first day in all tubes were comparable $(5.9 \pm 0.1$ $-6.3 \pm 0.3 \mathrm{mg} \mathrm{dm}^{-3}$ ), and after seven days, we have observed their substantial decrease to $2.4 \pm$ $0.3-4.0 \pm 0.4 \mathrm{mg} \mathrm{dm}^{-3}$. The performed aeration improved the oxygen conditions, nevertheless, by the last day, the oxygen concentrations were lower in

$D+7$, and $D+14-$ consecutive days of the experiment; single asterisk $P<0.05$, double asterisk $P<0.01$, differences against controls at $\mathrm{D}+1$, one-way ANOVA)

comparison to the initial, and in one case, they reached a very low level $\left(2.8 \pm 0.4 \mathrm{mg} \mathrm{dm}^{-3}\right.$ in G10, Fig. 1d). Base phosphate concentrations in C, G5, and G10 tubes ranged from $0.017 \pm 0.007$ to $0.044 \pm 0.024 \mathrm{mg} \mathrm{dm}^{-3}$ and fluctuated slightly (increased or decreased) throughout the study period. Distinctively higher values $(F=11.4, P<0.05)$ occurred in the tubes enriched with the peat extract (Fig. 1e). Electrolytic conductivity oscillated in all tubes-between 31.0 and $33.0 \mu \mathrm{S} \mathrm{cm}^{-1}$.

On the day following the setting up of the experiment, we found Gonyostomum germlings in all 
Fig. 2 Changes in Gonyostomum semen germling cell numbers in control and experimental tanks ( $C$ control, $G 55 \mathrm{mg}$ of glucose addition, $G 10$ $10 \mathrm{mg}$ of glucose addition, $P$ peat extract addition; $D+1, D+7$, and $D+14$ - consecutive days of the experiment)

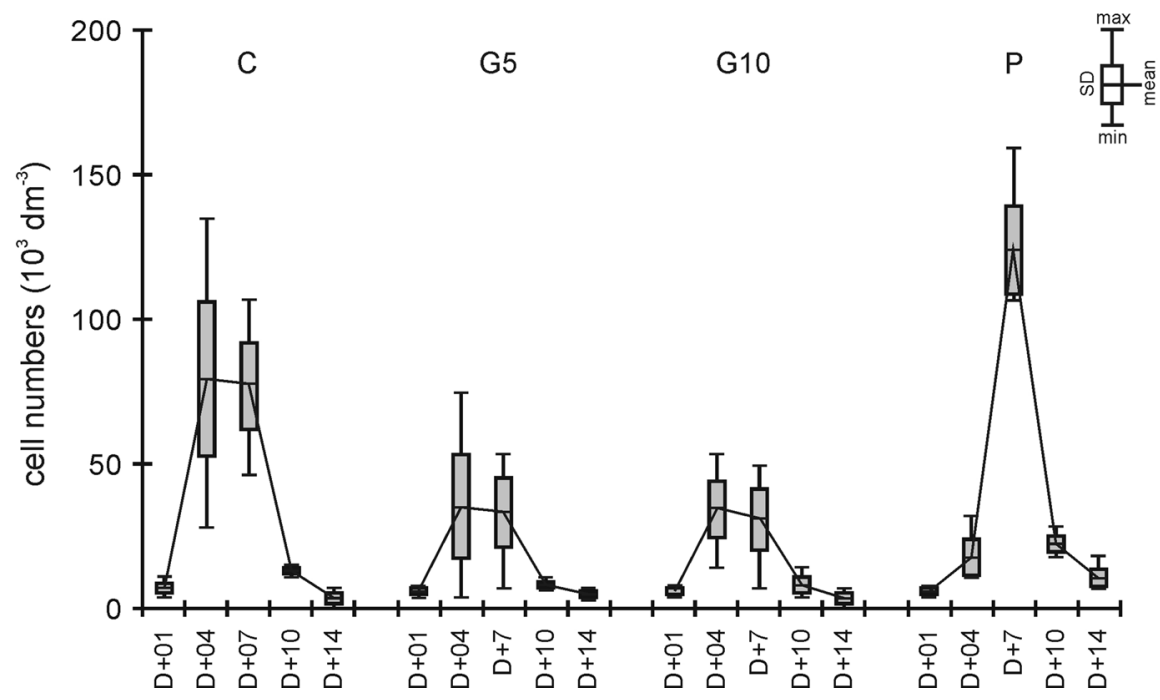

Table 1 Results of main effects ANOVA on number of germlings, testing for the effect of DOC and $\mathrm{P}_{-} \mathrm{PO}_{4}$

\begin{tabular}{lcccll}
\hline & df & SS & MS & $F$ & $P$ \\
\hline Number of germlings & & & & \\
Intercept & 1 & 2.43 & 2.43 & 98.30 & $<\mathbf{0 . 0 0 1 * *}$ \\
DOC & 3 & 6.61 & 2.20 & 8.91 & $<\mathbf{0 . 0 0 1} * *$ \\
${\mathrm{P}-\mathrm{PO}_{4}}^{\text {DOC } \times \mathrm{P}^{*} \mathrm{PO}_{4}}$ & 2 & 2.92 & 1.45 & 58.70 & $<\mathbf{0 . 0 0 1 * *}$ \\
\hline
\end{tabular}

** significant at the level $P<0.01$

tanks, but at low numbers $\left(6.2 \pm 2.2 \times 10^{3} \mathrm{dm}^{-3}\right.$, mean for all samples). On the fourth and the seventh day, elevated germling counts were noted in both controls and the two glucose treatments. In the controls, these values amounted $79.1 \pm 53.3 \times 10^{3}$ and $76.7 \pm 30.1 \times 10^{3} \mathrm{dm}^{-3}$ respectively, while in the $\mathrm{G}$ tanks, they were two-fold lower $\left(30.7 \times 10^{3}\right.$ $-35.4 \times 10^{3} \mathrm{dm}^{-3}$; Fig. 2). On the consecutive day sampling, the values were low, comparable to the first day. A different pattern was evident with respect to the peat tubes. These showed a distinctively higher abundance only on the seventh day. Furthermore, their mean value $\left(124.0 \pm 30.7 \times 10^{3} \mathrm{dm}^{-3}\right)$ was almost twice as high as in the control on the corresponding day of sampling. On the directly preceding and following days (fourth and tenth), germling cell numbers amounted to $17.7 \pm 12.2$ $\times 10^{3}$ and $22.4 \pm 5.4 \times 10^{3} \mathrm{dm}^{-3}$, respectively
(Fig. 2). Finally, main effect analysis of variance reveals that DOC and phosphates (each one separately as well as both together) significantly affected germling occurrence in the water above the sediments (Table 1).

Mature cell numbers showed a different pattern of changes (Fig. 3). In the control tubes, during the experiment, we observed two subsequent periods of population change, an increase (to $73.2 \pm 28.8 \times 10^{3}$ $-74.4 \pm 7.1 \times 10^{3} \mathrm{dm}^{-3}$ ) and a decrease (to 20.1 $\pm 10.8 \times 10^{3}-21.2 \pm 12.7 \times 10^{3} \mathrm{dm}^{-3}$ ) between the first and the seventh day, as well as between the seventh and the last day. Similar dynamics were noted in the glucose treatments, although the peak values were lower (Fig. 3). Interestingly, in the tubes with peat extract addition, the mature cell numbers increased continuously until the tenth day, reaching $114.5 \pm 44.8 \times 10^{3}$ $\mathrm{dm}^{-3}$. Afterwards, the values declined to $38.9 \pm 19.7$ $\times 10^{3} \mathrm{dm}^{-3}$ by the last day.

\section{Discussion}

Our first important finding (although unintended with respect to the main goal of the research) was that Gonyostomum semen recruitment was uneven during the experiment. The maximal abundance of cells observed at the fourth and the seventh day indicates that the period of germination of the species at $16^{\circ} \mathrm{C}$ is relatively short. Moreover, the mean numbers of cells in the water column above the sediments in controls 
Fig. 3 Changes in Gonyostomum semen adult cell numbers in control and experimental tanks ( $C$ control, G5 $5 \mathrm{mg}$ of glucose addition, $G 10$ $10 \mathrm{mg}$ of glucose addition, $P$ peat extract addition; $D+1, D+7$, and $D+14$ - consecutive days of the experiment)

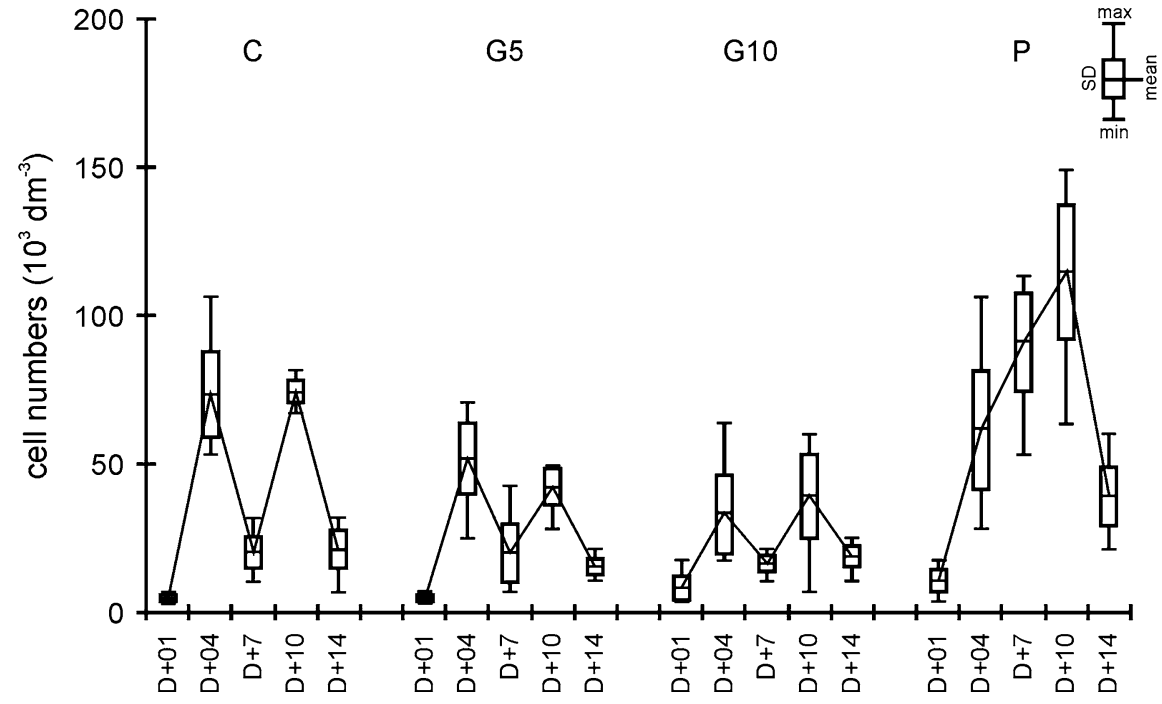

after the fourth day were $79.1 \times 10^{3} \mathrm{dm}^{-3}$, which corresponds to the germination rate of $8.47 \times 10^{6} \mathrm{~m}^{-2} \mathrm{day}^{-1}$. The value is lower than that noted by Hansson (1996), which showed the germination rate of ca. $28 \times 10^{6} \mathrm{~m}^{-2}$ day $^{-1}$ after five days of an experiment examining the impact of grazers on Gonyostomum recruitment, but at a temperature of $18^{\circ} \mathrm{C}$. Previous research (Figueroa \& Rengefors, 2006; Rengefors et al., 2012) have shown that higher temperatures promote the germination of cysts out of dormancy, therefore, the $2^{\circ} \mathrm{C}$ lower temperature in our experiment may explain the observed difference in the germination rate.

The present study was designed primarily to determine the effect of various forms of DOC addition on $G$. semen recruitment. Statistical analyses revealed that DOC significantly affected germling occurrence in water. However, DOC addition in the form of sugar (without phosphates), regardless of its dose, seemed to suppress germling appearance, whereas, when added as a peat extract (which resulted also in increased phosphate content), an improvement came about. Moreover, peat extract delayed the time of the largest recruitment by about 3 days. The fact that the elevated sugar-derived DOC (with zero phosphorus increase) led to the decrease of the alga recruitment could suggest, that it was the increased phosphorus concentrations in the peat treatment that played a major role in the observed differences.

These findings are consistent with those of Findlay et al. (2005), who found that phosphorus addition of
$0.05 \mathrm{mg} \mathrm{dm}^{-3}$ gave ten times higher biomass in the water above sediments after 8-11 days of the recruitment experiment. However, the authors counted all Gonyostomum cells (both germling and mature), so it is hard to distinguish whether phosphorus addition enhanced the germination or the growth rate of the species. Nevertheless, a number of studies reported the positive role of phosphorus in the germination of resting forms of various algal species. This effect was revealed for cysts of two dinoflagellates: Ceratium hirundinella (Rengefors \& Anderson, 1998) and Gymnodinium catenatum (Figueroa et al., 2006), zoospores of Cladophora glomerata and Rhizoclonium hieroglyphicum (Agrawal \& Misra, 2002), akinetes of various cyanobacteria species (Hüber, 1985; van Dok \& Hart, 1997; Agrawal \& Misra, 2002) or Enteromorpha sp. spores (Sousa et al., 2007). The influence of phosphorus on germination success is explained by the ability of cysts to uptake nutrients, as it was suggested by Rengefors et al. (1996) in regard to dinoflagellate Scrippsiella trochoidea. According to Agrawal (2009), the lack of phosphorus, which decreases spore or cyst germination in algae, indicates the synthesis of fresh nucleic acids during this process. Nevertheless, there are also reports revealing the lack of the effect of nutrients (including phosphorus) on the algal cyst germination (Sako et al., 1985; Binder \& Anderson, 1987; Cannon, 1993). Moreover, the research we have conducted prior to this experiment, concerning long-term changes in phytoplankton community of Lake Płotycze (the same lake from which 
the sediments had been used in this experiment) reveals that, after the rising of the water level, the community had been dominated by Gonyostomum semen, which was accompanied with DOC increase, but phosphorus decrease (Pęczuła \& Szczurowska, 2013).

Other possible explanation of our findings may be related to the content of dissolved organic compounds in the peat extract. It is known, that the growth rate of Gonyostomum is supported by fulvic acids (Rengefors et al., 2008), which may explain the continuous increase of adult cell numbers in our experimental peat tanks, in contrast to controls and glucose treatments. Humic substances have been also shown to positively affect the growth rate of some dinoflagellates (Prakash \& Rashid, 1968; Doblin et al., 1999; Gagnon et al., 2005); however, there is no single study concerning the impact of humic substances on any algal cyst germination.

Unfortunately, we cannot distinguish the effects of peat-derived DOC and phosphorus on the enhanced germination in the treatments with peat extract. Moreover, a combined effect of both factors is very likely, as the peat extract certainly contained an extra amount of phosphorus, present in the form of humicmetal ion complexes (Petrovic \& Kastelan-Macan, 1996; Gerke, 2010). Utilization of DOC by bacteria, which are subsequently grazed by heterotrophic flagellates, leads to phosphorus regeneration and its renewed availability for phytoplankton (Granéli et al., 1999). The possible enhanced bacterial growth during our experiment was visible in changes of chemical parameters (a substantial decrease of DOC and oxygen content in the treatments).

In contrast to our use of peat extract within the experiment, the addition of glucose seemed to inhibit the recruitment of Gonyostomum, which was a rather unexpected finding. It is difficult to explain this result, but it might be related to an oxygen decline which occurred in all the tanks, but was most evident in the G5 and G10 treatments, as anoxic or very low oxygen conditions are known to inhibit or prevent germination of various protistan cysts, such as in the dinoflagellates (Anderson et al., 1987; Ishikawa \& Taniguchi, 1994; Kremp \& Anderson, 2000). Although in our experimental tanks we did not observed such severe conditions (the oxygen level never dropped below $2 \mathrm{mg} \mathrm{dm}^{-3}$, mainly due to the aeration within the experiment), we cannot exclude this factor, as knowledge of the impact of oxygen conditions on Gonyostomum cyst germination is lacking. The performed aeration certainly rearranged the environmental conditions, which might have disrupted germination trends. This may be regarded as a limitation of our study design, but the manipulation was applied to all treatments (including controls), so the conclusions based on observed differences between tubes seem to be valid.

Another possible, although speculative, explanation for lower recruitment in sugar treatments is that glucose addition might bring about the enhanced growth of the bacteria and heterotrophic nannoflagellates (as we have concluded above, on the basis of changes in DOC and $\mathrm{O}_{2}$ content). The same phenomenon was observed during a whole-lake experiment with sucrose addition (Blomqvist et al., 2001). What is more, previous research has realized that some bacteria may produce a variety of compounds, including toxic proteins, polyanionic polymers, substituted alkaloids, and cyclic peptides, which showed inhibitory activity on some algal spores germination (review in: Agrawal, 2009).

Although we cannot differentiate the effects of DOC and phosphorus, our findings revealed that some peat-derived compounds enhanced the recruitment of G. semen cysts from sediments. Thus, we have shown that germination of Gonyostomum cysts may be regulated not only by the temperature (Figueroa \& Rengefors, 2006) or the presence of the grazers (Hansson, 1996, 2000), but also by the allochthonous chemicals derived from peat. What are the ecological implications of our finding? The amount of compounds reaching the lake from peatland catchments is regulated by hydrometeorological factors (Schindler \& Curtis, 1997; Hudson et al, 2003), which are significantly impacted by recent climate change (Whitehead et al., 2009). For example, since the end of the last century, various reports have shown considerable DOC increase in the freshwaters of Northern and Central Europe (Hejzlar et al., 2003; Worrall et al., 2004; Evans et al., 2005; Monteith et al., 2007). These observed changes have been linked to such factors as increase of air temperature, rainfall intensity and atmospheric carbon dioxide, or a decline in acid deposition, although their detailed role are still under debate (Delpla et al., 2009). Recent scientific developments in freshwater ecology have highlighted the actual and predicted impact of climate change also 
on the increase of phosphorus loadings to lakes (Jeppesen et al., 2009). In the light of our findings, we can propose that one of the mechanisms of Gonyostomum semen expansion throughout European freshwaters in the last decades is related to the enhanced recruitment of the species from sediment seed banks, and this has been influenced by climate change-driven water chemistry. This hypothesis stays in agreement with suggestions proposed by Rengefors et al. (2012) that global warming supports Gonyostomum expansion and blooms in Europe, not only by the increase of the temperature, but, indirectly, also by the increase of DOC concentrations in freshwaters. Further studies concerning the role of oxygen, phosphorus and humic acids, as well as the role of bacteria in Gonyostomum semen cyst germination, will be of great help in our understanding of this invasive and bloom-forming raphidophyte ecology within European freshwaters.

Acknowledgments The authors would like to thank the anonymous reviewers for their valuable comments and suggestions which improve the quality of the manuscript. We are also grateful to dr Monika Tarkowska-Kukuryk for the help in statistical analyses.

Open Access This article is distributed under the terms of the Creative Commons Attribution License which permits any use, distribution, and reproduction in any medium, provided the original author(s) and the source are credited.

\section{References}

Agrawal, S. C., 2009. Factors affecting spore germination in algae - review. Folia Microbiologica 54: 273-302.

Agrawal, S. C. \& U. Misra, 2002. Vegetative survival, akinete and zoosporangium formation andgermination in some selected algae as affected by nutrients, $\mathrm{pH}$, metals, and pesticides. Folia Microbiologica 47: 527-534.

Anderson, D. M. \& K. Rengefors, 2006. Community assembly and seasonal succession of marine dinoflagellates in a temperate estuary: the importance of life cycle events. Limnology and Oceanography 51: 860-873.

Anderson, D. M. \& D. Wall, 1978. Potential importance of benthic cysts of Gonyaulax tamarensis and G. excavata in initiating toxic dinoflagellate blooms. Journal of Phycology 14: 224-234.

Anderson, D. M., C. D. Taylor \& E. V. Armbrust, 1987. The effects of darkness and anaerobiosis on dinoflagellate cyst germination. Limnology and Oceanography 32: 340-350.

Binder, B. J. \& D. M. Anderson, 1987. Physiological and environmental control of germination in Scrippsiella trochoidea (Dinophyceae) resting cysts. Journal of Phycology 23: 99-107.

Blomqvist, P., M. Jansson, S. Drakare, A.-K. Bergstrom \& L. Brydsten, 2001. Effects of additions of DOC on pelagic biota in a clearwater system: results from a whole lake experiment in northern Sweden. Microbial Ecology 42: 383-394.

Cannon, J. A., 1993. Germination of the toxic dinoflagellate, Alexandrium minutum, from sediments in the Port River, South Australia. In Smayda, T. \& Y. Shimizu (eds), Toxic Phytoplankton Blooms in the Sea. Elsevier, New York: 103-107.

Cronberg, G., G. Lindmark \& S. Björk, 1988. Mass development of the flagellate Gonyostomum semen (Raphidophyta) in Swedish forest lakes - an effect of acidification? Hydrobiologia 161: 217-236.

Delpla, I., A. V. Jung, E. Baures, M. Clement \& O. Thomas, 2009. Impacts of climate change on surface water quality in relation to drinking water production. Environment International 35: 1225-1233.

Doblin, M. A., S. I. Blackburn \& G. M. Hallegraeff, 1999. Growth and biomass stimulation of the toxic dinoflagellate Gymnodinium catenatum (Graham) by dissolved organic substances. Journal of Experimental Marine Biology and Ecology 236: 33-47.

Eloranta, P. \& A. Palomäki, 1986. Phytoplankton in lake Konnevesi with special reference to eutrophication of the lake by fish farming. Aqua Fennica 16: 37-45.

Evans, C. D., D. T. Monteith \& D. M. Cooper, 2005. Long-term increases in surface water dissolved organic carbon: observations, possible causes and environmental impacts. Environmental Pollution 137: 55-71.

Figueroa, R. I. \& K. Rengefors, 2006. Life cycle and sexuality of the freshwater raphidophyte Gonyostomum semen (Raphidophyceae). Journal of Phycology 42: 859-871.

Figueroa, R. I., I. Bravo, E. Garcés \& I. Ramilo, 2006. Nuclear features and effect of nutrients on Gymnodinium catenatum (Dinophyceae) sexual stages. Journal of Phycology 42: 67-77.

Findlay, D. L., M. J. Paterson, L. L. Hendzell \& H. J. Kling, 2005. Factors influencing Gonyostomum semen blooms in a small boreal reservoir lake. Hydrobiologia 533: 243-252.

Fryxell, G. A., 1983. Survival Strategies of the Algae. Cambridge University Press, New York.

Gagnon, R., M. Levasseur, A. M. Weise, J. Fauchot, P. G. C. Campbell, B. J. Weissenboeck, A. Merzouk, M. Gosselin \& B. Vigneault, 2005. Growth stimulation of Alexandrium tamarense (Dinophyceae) by humic substances from the Manicouagan River (Eastern Canada). Journal of Phycology 41: 489-497.

Gerke, J., 2010. Humic (organic matter)-Al(Fe)-phosphate complexes: an underestimated phosphate form in soils and source of plant-available phosphate. Soil Science 175: 417-425.

Górniak, A., P. Zieliński, E. Jekatierynczuk-Rudczyk, M. Grabowska \& T. Suchowolec, 2002. The role of dissolved organic carbon in a shallow lowland reservoir ecosystem a long-term study. Acta Hydrochimica et Hydrobiologica 30: 179-189.

Granéli, E., P. Carlsson \& C. Legrand, 1999. The role of C, N and $\mathrm{P}$ in dissolved and particulate organic matter as a 
nutrient source for phytoplankton growth, including toxic species. Aquatic Ecology 33: 17-27.

Hansson, L. A., 1996. Behavioural response in plants: adjustment in algal recruitment induced by herbivores. Proceedings of the Royal Society B 263: 1241-1244.

Hansson, L. A., 2000. Synergistic effects of food chain dynamics and induced behavioral responses in aquatic ecosystems. Ecology 81: 842-851.

Hehmann, A., L. Krienitz \& R. Koschel, 2001. Long term phytoplankton changes in an artificially divided, top-down manipulated humic lake. Hydrobiologia 448: 83-96.

Hejzlar, J., M. Dubrovský, J. Buchtele \& M. Růžička, 2003. The apparent and potential effects of climate change on the inferred concentration of dissolved organic matter in a temperate stream (the Malše River, South Bohemia). Science of the Total Environment 310: 143-152.

Hermanowicz, W., W., Dożańska, J., Dojlido, \& B. Kosiorowski, 1976. Fizyczno-chemiczne badanie wody i ścieków [Physical and chemical examination of water and wastewater]. Arkady, Warszawa, (in Polish).

Hongve, D., Ø. Løvstad \& K. Bjørndalen, 1988. Gonyostomum semen - a new nuisance to bathers in Norwegian lakes. Verhandlungen des Internationalen Verein Limnologie 23: 430-434.

Hüber, A. L., 1985. Factors affecting the germination of akinetes of Nodularia spumigena (Cyanobacteriaceae). Applied Environmental Microbiology 49: 73-78.

Hudson, J. J., P. J. Dillon \& K. M. Somers, 2003. Long-term patterns in dissolved organic carbon in boreal lakes: the role of incident radiation, precipitation, air temperature, southern oscillation and acid deposition. Hydrology and Earth System Sciences 7: 390-398.

Hutorowicz, A., 1993. Gonyostomum semen (Raphidophyceae) in Lake Smolak in northern Poland. Fragmenta Floristica et Geobotanica Polonica 38: 163-171.

Ishikawa, A. \& A. Taniguchi, 1994. The role of cysts on population dynamics of Scrippsiella spp. (Dinophyceae) in Onagawa Bay, northeast Japan. Marine Biology 119: 39-44.

Jeppesen, E., B. Kronvang, M. Meerhoff, M. Søndergaard, K. M. Hansen, H. E. Andersen, T. L. Lauridsen, M. Beklioglu, A. Özen \& J. E. Olesen, 2009. Climate change effects on runoff, catchment phosphorus loading and lake ecological state, and potential adaptations. Journal of Environmental Quality 38: 1930-1941.

Karosienè, J., J. Kasperovičienè, J. Koreivienè \& I. Vitonyte, 2014. Assessment of the vulnerability of Lithuanian lakes to expansion of Gonyostomum semen (Raphidophyceae). Limnologica 45: 7-15.

Korneva, L. G., 2000. Ecological aspects of the mass development of Gonyostomum semen (Ehr.) Dies. (Raphidophyta). Algologia 10: 265-277.

Kremp, A. \& D. M. Anderson, 2000. Factors regulating germination of resting cysts of the spring bloom dinoflagellate Scrippsiella hangoei from the northern Baltic Sea. Journal of Plankton Research 22: 1311-1327.

Laugaste, R., 1992. An alga of genus Gonyostomum. Eesti Loodus 12: 610-612.

Lepistö, L. \& M. Saura, 1998. Effects of forest fertilisation on phytoplankton in boreal brown-water lake. Boreal Environment Research 3: 33-43.
Lepistö, L., S. Antikainen \& J. Kivinen, 1994. The occurance of Gonyostomum semen (Ehr.) Diesing in Finnish lakes. Hydrobiologia 273: 1-8.

Monteith, D. T., J. L. Stoddard, C. D. Evans, H. A. de Wit, M. Forsius, T. Høgåsen, A. Wilander, B. L. Skjelkvåle, D. S. Jeffries, J. Vuorenmaa, B. Keller, J. Kopácek \& J. Vesely, 2007. Dissolved organic carbon trends resulting from changes in atmospheric deposition chemistry. Nature 450: 537-540.

Noges, P. \& R. Laugaste, 2002. Nuisance alga Gonyostomum semen. Implications for its global expansion. In Ahalya, T. V. (ed.), LAKE 2002 Symposium on Conservation, Restoration and Management of Aquatic Ecosystems. Capital Publishing Company, New Delhi: 77-87.

Nürnberg, G. \& M. Shaw, 1998. Productivity of clear and humic lakes: nutrients, phytoplankton, bacteria. Hydrobiologia 382: 97-112.

Pace, M. P. \& J. J. Cole, 2002. Synchronous variation of dissolved organic carbon and color in lakes. Limnology and Oceanography 47: 333-342.

Petrovic, M. \& M. Kastelan-Macan, 1996. The uptake of inorganicphosphorus by insoluble metal-humic complexes. Water Science and Technology 34: 253-258.

Pęczuła, W., 2007. Mass development of the algal species Gonyostomum semen (Raphidophyceae) in the mesohumic Lake Płotycze (central-eastern Poland). Oceanological and Hydrobiological Studies 36: 163-172.

Pęczuła, W., 2013. Habitat factors accompanying the mass appearances of nuisance algal species Gonyostomum semen (Ehr.) Diensig in humic lakes of Eastern Poland. Polish Journal of Ecology 61: 535-543.

Pęczuła, W. \& A. Szczurowska, 2013. Long term changes in the humic lake phytoplankton in response to the water level rising: the effects of beavers engineering on a freshwater ecosystem. Knowledge and Management of Aquatic Ecosystems 410: 06. doi:10.1051/kmae/2013061.

Prakash, A. \& M. A. Rashid, 1968. Influence of humic substances on the growth of marine phytoplankton: dinoflagellates. Limnology and Oceanography 13: 598-601.

Rengefors, K. \& D. M. Anderson, 1998. Environmental and endogenous regulation of cyst germination in two freshwater dinoflagellates. Journal of Phycology 34: 568-577.

Rengefors, K., D. M. Anderson \& K. Pettersson, 1996. Phosphorus uptake by resting cysts of the marine dinoflagellate Scrippsiella trochoidea. Journal of Plankton Research 18: 1753-1765.

Rengefors, K., C. Palsson, L. A. Hansson \& L. Heiberg, 2008. Cell lysis of competitors and osmotrophy enhance growth of the bloom-forming alga Gonyostomum semen. Aquatic Microbial Ecology 51: 87-96.

Rengefors, K., G. A. Weyhenmeyer \& I. Bloch, 2012. Temperature as a driver for the expansion of the microalga Gonyostomum semen in Swedish lakes. Harmful Algae 18: 65-73.

Sako, Y., Y. Ishida, H. Kadota \& Y. Hata, 1985. Excystment in the freshwater dinoflagellate Peridinium cunningtonii. Bulletin Japanese Societies Sciences Fisheries 51: 267-272.

Schindler, D. W. \& P. J. Curtis, 1997. The role of DOC in protecting freshwaters subjected to climatic warming and acidification from UV exposure. Biogeochemistry 36: 1-8.

Schindler, D. W., S. E. Bayley \& P. J. Curtis, 1992. Natural and man-caused factors affecting the abundance and cycling of 
dissolved organic substances in precambrian shield lakes. In Salonen, K., T. Kairesalo \& R. I. Jones (eds), Dissolved Organic Matter in Lacustrine Ecosystems. Springer, Netherlands: 1-21.

Sousa, A. I., I. Martins, A. I. Lillebø, M. R. Flindt \& M. A. Pardal, 2007. Influence of salinity, nutrients and light on the germination and growth of Enteromorpha sp. spores. Journal of Experimental Marine Biology and Ecology 341: 142-150.

Van Dok, W. \& B. T. Hart, 1997. Akinete germination in Anabaena circinalis (Cyanophyta). Journal of Phycology 33: 12-17.

Vollenweider, R. A., 1969. A Manual on Methods for Measuring Primary Production in Aquatic Environments. Blackwell, Oxford.

Vuorenmaa, J., M. Forsius \& J. Mannio, 2006. Increasing trends of total organic carbon concentrations in small forest lakes in Finland from 1987 to 2003. Science of the Total Environment 365: 47-65.

Wetzel, R. G., 1992. Gradient-dominated ecosystems: sources and regulatory functions of dissolved organic matter in freshwater ecosystems. Hydrobiologia 229: 181-198.

Whitehead, P. G., R. L. Wilby, R. W. Battarbee, M. Kernan \& A. J. Wade, 2009. A review of the potential impacts of climate change on surface water quality. Hydrological Sciences Journal 54: 101-123.

Willen, E., 2003. Dominance patterns of planktonic algae in Swedish forest lakes. Hydrobiologia 502: 315-324.

Worrall, F., T. Burt \& J. Adamson, 2004. Can climate change explain increases in DOC flux from upland peat catchments? Science of the Total Environment 326: 95-112. 